\title{
MARKET ASSESSMENT OF PFBC ASH USE
}

\author{
Alan E. Bland (ABland@UWYO.edu; 307-721-2386) \\ Terry H. Brown (TBrown@UWYO.edu: 307-721-2457) \\ Western Research Institute \\ $365 \mathrm{~N}$ 9th Street \\ Laramie, WY 82070-3380
}

\section{Contract Information}

Contract Number:

Period of Performance:

Contractor:

Contractor Project Manager:

Industrial Co-Sponsors:

FETC COR:
DE-FC21-93MC3027

March 1993 - March 1998

Western Research Institute

Dr. Alan E. Bland

Foster Wheeler Energy International, Inc.

Electric Power Research Institute

Dr. Kamalendu Das

\section{Abstract}

Pressurized fluidized bed combustion (PFBC) of coal is undergoing demonstration in the United States, as well as throughout the world. American Electric Power's (AEP) bubbling PFBC $70 \mathrm{MW}_{\mathrm{e}}$ Tidd demonstration program in Ohio and pilot-scale development at Foster Wheeler Energia Oy $10 \mathrm{MW}_{\text {th }}$ circulating PFBC at Karhula, Finland, have demonstrated the advantages of PFBC technology. Further technology development in the U.S. is planned with the deployment of the technology at the MacIntosh Clean Coal project in Lakeland, Florida.

Development of uses for solid wastes from PFBC coal-fired power systems is being actively pursued as part of the demonstration of PFBC technologies. Ashes collected from Foster Wheeler Energia Oy pilot circulating PFBC tests in Karhula, Finland, operating on (1) low-sulfur subbituminous and (2) highsulfur bituminous coal; and ash from the
AEP's high-sulfur bituminous coal-fired bubbling PFBC in Brilliant, Ohio, were evaluated in laboratory and pilot-scale ash-use testing at Western Research Institute (WRI).

\section{Market Assessment}

A general review has been conducted of potential markets for PFBC ashes. This review indicated that there are a number of markets into which PFBC ash, derived from both high-sulfur and low-sulfur coal-fired units, may be able to penetrate, including:

- Supplementary cementing materials in concrete and cement production;

- Structural fill and embankment material;

- Soil stabilizing agent;

- Synthetic aggregate production; and

- Soil amendment

Unfortunately, the value of the product in these markets is governed by the availability 
of competing materials in the local transportation area. Competing materials, such as conventional power plant ashes are already established in many of these markets and have substantial technical performance records. As such, the technical specifications of PFBC ash in each of these market applications must be demonstrated before commercial acceptance can be realized.

\section{Technical Feasibility of PFBC Ash Use}

Ash use options evaluated for these PFBC ashes were construction-related applications, such as (1) cement production, (2) fills and embankment, (3) soil stabilization, synthetic aggregate production, as well as (5) an amendment for acidic and sodic soil and mine spoil. Testing has concluded the following:

- PFBC ash does not meet the American Society for Testing and Materials (ASTM) chemical requirements as a pozzolan for cement replacement (ASTM C-618). However, potential exists for its use as a pozzolan and as a set-retardant (gypsum replacement) in Type $\mathrm{P}$ portland cement production.

- PFBC ash shows relatively high strength development (>400 psi), low expansion $(<0.01 \%)$, and low permeabilities $(\mathrm{k}<10-5$ $\mathrm{cm} / \mathrm{sec}$ ), making it a viable fill and embankment material.

- $\quad$ Lime-enhanced (e.g., 3.6\% $\mathrm{CaO}$ added) PFBC ash develops high strengths $(>4,000 \mathrm{psi})$, manageable early expansion $(<1.5 \%$ in 7 days), and wet/dry and freeze/thaw cycle durability $(>1 \%$ loss after 12 cycles), making PFBC ash a suitable agent for soil stabilization applications.
- Synthetic aggregate produced with limeenhanced PFBC ash develops high crush strengths (>300 lbs.), Los Angeles (LA) abrasion resistance (10 to $30 \%$ loss) and soundness resistance $(<5 \%)$, making it an excellent material for synthetic aggregate production for construction applications.

- Laboratory equilibrium studies and greenhouse studies using Garrison Meadow Foxtail grass shows PFBC ash to be as effective as ag-lime in promoting seed germination and acid neutralization and more effective than ag-lime in promoting plant productivity and root penetration in acidic spoil. Permeability testing of sodic spoil indicates that PFBC ash is effective in modifying soil structure, resulting in the potential enhancement of root penetration and nutrient availability.

\section{Conclusions}

There is a significant market potential for PFBC ash in the construction and soil amendment industries. PFBC ash represents a technically viable material, as evidenced by the WRI findings, for use in many of the same markets currently established by conventional coal combustion ashes. In conclusion, PFBC ash should be viewed as a valuable resource, and commercial opportunities for these materials should be explored for future PFBC installations.

\section{INTRODUCTION}

Pressurized fluidized bed combustion (PFBC) represents one of the most promising emerging Clean Coal Technologies (CCT). PFBC has been demonstrated at near commercial scale at the American Electric Power (AEP) Tidd bubbling PFBC demonstration plant in Ohio, as well as at Vartan in Sweden, and Escatron in Spain. 
Circulating PFBC technology is being demonstrated at the pilot-scale at Foster Wheeler Energia Oy in Karhula, Finland.

The utilization of ash from fluidized bed combustion (FBC) units is a promising ash management option. The chemical characteristics of pressurized fluidized bed combustion ash compared to other FBC ashes have generated interest in the use of PFBC ash for various construction and agricultural applications. However, before commercial entities are ready to commit to the concept of using PFBC ash, its performance in viable applications must be documented.

Western Research Institute (WRI), is completing a three-year project under sponsorship of the Electric Power Research Institute (EPRI), Foster Wheeler Energy International, Inc., and the U.S. Department of Energy (DOE), Federal Energy Technology Center (FETC) that addresses ash use markets and options for PFBC technologies.

The overall objectives of this study are to determine the market potential and the technical feasibility of using PFBC ash in high-volume use applications. The study is of direct use to the utility industry in assessing the economics of PFBC power generation, particularly in light of ash disposal avoidance achieved through ash use. Additional benefits can be realized by a utility through $\mathrm{CO}_{2}$ offset credits resulting from ash penetration into certain markets that generate high levels of greenhouse gases during manufacturing (e.g., cement production).

The specific objectives of the program are:

- to define present and future market potential of PFBC ash for a range of applications;
- to assess the technical feasibility of PFBC ash use in construction and soil/spoil amendment applications; and

- to demonstrate the most promising of the ash use options in full-scale field demonstrations.

This paper addresses the results of (1) a general review of the markets for PFBC ashes, and (2) the technical feasibility of ash use options for PFBC units using low-sulfur and high-sulfur coal and limestone sorbent derived ashes (Karhula-low ashes and Karhula-high ashes) and high-sulfur coal and dolomite sorbent-derived ash (AEP Tidd ash).

\section{POTENTIAL MARKETS FOR PFBC ASH}

Conventional power plant ash and FBC residue have been evaluated and used as engineering and construction materials for over a decade. A summary of FBC ash use in construction applications was provided by Bland (1994). The building construction, road and highway construction, coal mining and reclamation, agricultural and, recently, environmental restoration industries have all been markets for these coal combustion byproducts. These industries consume enormous quantities of raw materials, and power plant ash has found acceptance.

The building industry has used fly ash as a raw material in cement production and cement replacement in concrete and concrete products, such as masonry units. Production of lightweight aggregate for concrete and concrete products has also been commercially practiced. Recently, FBC ash and flue-gas desulfurization (FGD) sludge have also been used in the building materials industry in such applications as wallboard production. 
The construction industry has used power plant ashes in a number of applications, including road and highway construction, airport runways, and dams and other earthen and concrete structures. Road construction has traditionally involved ash in a number of techniques and materials, such as roller compacted concrete (RCC), soil stabilization, stabilized road subbases and bases, embankments and fills, engineered material for structural fills, synthetic construction aggregate production for concrete, asphalt paving, and road base construction.

The mining industry has used power plant ash for a number of years as a reclamation and soil/spoil amendment, for subsidence control in underground mines, for haul road stabilization, and for embankments and fills.

The agriculture industry is becoming a market for power plant ashes. Atmospheric fluidized bed combustion (AFBC) ash, in particular, is finding acceptance in a number of states in agricultural applications. In this industry, the ash is used as a lime and sulfate source, micro- and macro-nutrient source, soil structure modifier, and moisture barrier for root growth.

Each of these market industries has the potential to consume large volumes of PFBC ash. An example of the market magnitude and potential for ash use can be seen in road and highway construction materials use statistics (Table 1).

The road construction industry consumes a tremendous amount of raw material, including earthen borrow, aggregates, portland cement, asphalt cement, mineral fillers, and lesser amounts of lime.

Earthen borrow is used as a fill, backfill, or embankment material. Aggregates are used as subbase or base material, as well as in concrete and asphalt paving.

Mineral fillers, such as rock fines and ash, are used in asphalt paving mixtures. Lime is also used as a stripping agent in asphalt, as well as a stabilizing agent for soils and road subbases and bases. Ash use in this market has reached 4.4 to 5.5 million tonnes ( 4 to 5 million tons) per year.

\section{Table 1. Raw Materials Use in Road and Highway Construction Industry*}

\begin{tabular}{|c|c|c|c|c|}
\hline Materials Consumed & $\begin{array}{l}\text { Potential Replacement } \\
\text { by PFBC Ash }\end{array}$ & $\begin{array}{c}\text { Road Bases/ } \\
\text { Subbases } \\
\text { (million tonnes) } \\
\end{array}$ & $\begin{array}{c}\text { Asphalt } \\
\text { Paving } \\
\text { (million tonnes) }\end{array}$ & $\begin{array}{c}\text { Concrete Paving, } \\
\text { Bridges, etc. } \\
\text { (million tonnes) }\end{array}$ \\
\hline $\begin{array}{l}\text { Aggregate } \\
\text { Crushed Stone, } \\
\text { Sand and Gravel } \\
\quad \text { Total } \\
\text { Cement } \\
\\
\text { Lime } \\
\text { Asphalt } \\
\text { Mineral Filler } \\
\text { Fly Ash } \\
\text { Bottom Ash }\end{array}$ & $\begin{array}{l}\text { Synthetic Aggregate } \\
\text { from PFBC Ash } \\
\\
\text { Cement/Concrete and } \\
\text { Soil Stabilization } \\
\text { No Replacement } \\
\text { No Replacement } \\
\text { PFBC Ash as Filler } \\
\text { PFBC Fly Ash } \\
\text { PFBC Bed Ash }\end{array}$ & $\begin{array}{c}220 \\
165 \\
385 \\
1.1 \text { (est.) } \\
0.88 \\
\\
0.55 \\
0.44 \text { to } 0.55\end{array}$ & $\begin{array}{c}237 \\
110 \text { to } 138 \\
347 \text { to } 374\end{array}$ & $\begin{array}{c}220-264 \\
\text { Crushed Stone, } \\
\text { Sand and Gravel } \\
220-264 \\
17.5 \text { to } 22.0\end{array}$ \\
\hline
\end{tabular}

Total Conventional Ash Production (1987) 68.9 million tons. Total Conventional Ash Use (1987) 18.3 million tons.

* Does not include earthen materials for fills and embankments, for which 2 million tons of fly ash were used in 1987.

Source: Compiled from data presented by Baker (1990) DOE/MC/25042-2872 


\section{Ash Use as a Supplementary Cementing Material in Concrete and Cement Production}

PFBC ash appears to be technically feasible for use in the cement industry. There are essentially three applications for PFBC ash in cement, including (1) replacement of cement in portland cement concrete; (2) pozzolanic material in the production of pozzolanic cements (e.g., Type IP); and (3) set retardant interground with cement as a replacement of gypsum.

In 1987, over 6.6 million tonnes (6 million tons) of conventional fly ash were used as a replacement for portland cement in ready-mix concrete and concrete products. This represented approximately $82 \%$ of all of the fly ash used in the United States. Approximately $42 \%$ of all ready-mix concrete used fly ash at an average of $20 \%$ replacement of the cement. These statistics have remained essentially unchanged over the last decade.

In 1992, over 88 million tonnes (80 million tons) of portland cement were produced in the United States. The use of conventional fly ash in the production of pozzolanic cement is estimated at approximately 1.1 million tonnes( 1 million tons).

In addition, approximately 3 to $5 \%$ of all portland cement employs the use of a retardant such as gypsum or anhydrite, which is interground with the clinker during the cement production process. This market represents in excess of 2.75 million tonnes (2.5 million tons).

Generally, PFBC ash may compete with conventional materials in each of these markets. Accordingly, in addition to the portland cement market opportunities, PFBC ash can also serve as a cementing material in the production of no-cement concrete and concrete products. AFBC ash use in nocement concrete and concrete products has been the subject of extensive development in the United States and Canada during the 1980s (Minnick, 1982; Bland et al., 1987, 1989a, b, 1991a, b; Burwell et al., 1993). This material, originally developed for subsidence control in underground mines, has been modified to have engineering properties comparable to those of portland cement concrete. The AFBC no-cement concrete has been tested in field demonstrations as a road base material, including as roller compacted concrete, as a ready-mix concrete, and as masonry block mix.

\section{Ash Use as Structural Fill and Embankment Materials}

The application of PFBC residue as an engineered material for structural fills and embankments represents a large-scale use option. Structural fills and embankments are numerous in the road construction, mining, and industrial construction industries. Structural fills and highway embankments using conventional ash materials have been well documented through EPRI-sponsored research and demonstration activities.

The potential use of AFBC residue for these construction applications relies on the development of a stable ash material. Georgiou, et al. (1993) investigated the potential for the structural fill of a quarry using ash from the AES Barbers Point circulating AFBC facility, Oahu, Hawaii. The study concluded that the construction of a structural fill using AFBC ash was technically feasible and that the ash produced a fill with a high degree of strength and stability.

Bigham et al. (1993) describe the use of bubbling bed PFBC ash in an embankment for 
a road in Ohio. The ash appears to have performed adequately in that demonstration (Beeghly et al., 1995).

\section{Ash Use for Soil Stabilization}

The use of PFBC ash and other FBC residues for stabilization of soils has been proposed as a potentially large ash use market. This ash use application is similar to the cement stabilization of soils commonly applied in the construction industry. Soil stabilization is based on the treatment of clay soils with a material to provide strength and stability. Cement, fly ash, and lime-ash materials are commonly employed at levels of 10 to $20 \%$ of the soil. FBC ashes exhibit self-cementing characteristics and, as such, have been proposed as a viable stabilizing agent. Unfortunately, certain FBC ashes with high sulfate contents may result in swelling and heaving of the soils. The use of low-sulfate PFBC residue or the use of PFBC ash in low concentrations with the soil appears promising, although caution is warranted.

The largest stabilization market is related to the stabilization of subbases and bases for road and highway construction. There are essentially two forms of stabilized road bases: (1) stabilization of a base material as a soil cement application, or (2) production of a stabilized road base material in a form such as roller compacted concrete. Both of these road base materials have potential for using ash (Bland et al., 1989a, b, 1991b). RCC is also used for other applications, such as dams and parking lots (Pitman, 1986). RCC made from AFBC ash has been demonstrated (Bland et al., 1989a, b, 1991b; Hunsacker et al., 1987). AFBC residue from the TVA 20 MW FBC facility in Paducah, Kentucky, was used in the RCC demonstration in McCracken County (Bland et al., 1989a, b; Hunsacker et al., 1987). PFBC ash is expected to be usable in this application, particularly in combination with controlled amounts of lime or cement.

The application of PFBC residue for the stabilization of cattle lots has been successfully demonstrated (Bigham et al., 1993; Beeghly et al., 1995). In this application, the PFBC residue is mixed into the soft cattle lot soils and allowed to cure. The PFBC residue removes water from the cattle lot soil and hardens. The resultant cattle lots show improved stability and reduced cattle hoof penetration.

\section{Ash Use in Synthetic Aggregate Production}

The aggregate market in the United States is enormous. In 1992, approximately 1.32 billion tonnes (1.2 billion tons) of crushed stone and approximately 0.88 billion tonnes ( 0.8 billion tons) of sand and gravel were produced for a market valued in excess of $\$ 8$ billion. The aggregate market encompasses conventional aggregate products, such as masonry units and ready-mix concrete. Also, with crushing, aggregates can be produced for use in asphalt paving, road base construction and even RCC. Lightweight aggregate can also be used in many structural building products.

Pelletizing plants for CFBC ashes have been built in the United States (Bland et al., 1993a; Bland, 1994). The pelletization of CFBC ash was selected for ease of handling and for the possible subsequent use as a synthetic aggregate. Preliminary testing of the pelletized ash as an aggregate indicates that the material meets the strength, abrasion resistance, and other engineering requirements for its use as an aggregate (Bland et al., 1993a). Pelletization offers a major market for PFBC ashes in the production of synthetic aggregate. In addition, pelletized PFBC ash 
can be stored during the construction offseason.

\section{Ash Use in Agricultural and Soil Amendment Applications}

PFBC ash use as a soil amendment for agricultural and reclamation activities represents a potentially large market. There are a number of benefits that result from the application of PFBC residue to agricultural soils or mine spoils. The benefits include the modification of soil $\mathrm{pH}$, supply of essential plant nutrients for crop production, increasing water infiltration, soil aggregation, and modification of soil structure, promoting root growth. An ash use data base for these applications resulting from years of research by universities has been compiled by the U.S. Department of Agriculture (USDA).

Ash use in agriculture has been promoted based on the presence of compounds such as lime and gypsum in the ashes (Korcak, 1980; Stout et al., 1988). As such, ash materials have the potential to be both a soil amendment and a nutrient source. Greenhouse studies have determined that the AFBC residue is as effective as ag-lime in increasing soil $\mathrm{pH}$ when the materials are applied in equivalent free lime rates. AFBC ash materials can also be an excellent source of magnesium, when dolomite is used as a sorbent. Application rates of $\mathrm{AFBC}$ residue at 2.2 to 11.2 tonnes per hectare ( 1 to 5 tons per acre) to agricultural lands with acidic soils, soils high in heavy metals, or soils deficient in trace metals can be beneficial.

PFBC and other FBC ashes can also be used as a soil amendment and nutrient source for revegetation of disturbed lands resulting from mining (Bennett et al., 1985; Stout et al., 1982; Sidle et al., 1978). The application of FBC residue to acidic soils and strip mine spoil can reduce the mobility of heavy metals through $\mathrm{pH}$ adjustment. Also, beneficial micro- and macro-nutrients have been observed to move into the subsoil of infertile acidic soils and mine spoils after application of AFBC residue, thereby promoting root penetration.

PFBC ash is expected to also meet the requirements for soil amendment applications in agriculture and reclamation. Studies sponsored by U. S. DOE have examined the use of ash from the American Electric Power Tidd bubbling PFBC facility in a variety of greenhouse studies. The technical feasibility of FBC ash use in agricultural applications was examined, and magnesium imbalance was noted as a potential side effect for those FBC units using dolomite as the sorbent (Stehouwer and Sutton, 1992; Bigham et al., 1993, Beeghly et al., 1995).

\section{Summary}

In summary, this general review has indicated that there are a number of markets into which PFBC ash, derived from both high-sulfur and low-sulfur coal-fired units, may be able to penetrate. The value of the market products and the availability of competing materials will be controlled by transportation distances. Competing materials are already established in these markets and have substantial technical performance records. Research findings from the current program will accelerate the efforts to find beneficial uses for the PFBC ashes.

\section{TECHNICAL FEASIBILITY OF PFBC ASH USE}

\section{Ash Sources}

The study of PFBC ash use options has included three different ashes: (1) ash from the Foster Wheeler Energia Oy circulating 
PFBC pilot plant in Karhula Finland, burning low-sulfur subbituminous coal; (2) ash from the Foster Wheeler Energia Oy circulating PFBC pilot plant in Karhula, Finland, burning high-sulfur bituminous coal; and (3) ash from the AEP Tidd demonstration plant, burning high-sulfur bituminous coal. Two sets of fly ash and bed ash from the Foster Wheeler Energia Oy pilot-scale circulating PFBC unit in Karhula, Finland, represented the combustion of low-sulfur Powder River Basin subbituminous coal (Black Thunder) with limestone sorbent, and the combustion of high-sulfur coal with a limestone sorbent. Fly ash and bed ash from the AEP Tidd facility in Brilliant, Ohio, represented ash from the bubbling PFB combustion of high-sulfur Ohio No. 8 (Illinois Basin) coal and Plum Run dolomite.

\section{Test Methods}

The major element chemistry of the fly ash and bed ash from each of the PFBC sources was determined by X-ray fluorescence (XRF), using standard calibration curves. Phase identification of the fly ashes and bed ashes was determined by X-ray diffraction (XRD), by wet chemical methods described by ASTM C-25 and by methods described by Iribarne (1993).

Geotechnical testing was conducted according to ASTM procedures on a blend of the fly ash and bed ash combined in relative proportions as produced during combustion. This material is termed an ash blend. Moisture-density relationships were determined according to ASTM D-698 compactive effort. Test specimens of the ash blend were prepared at the optimum moisture and densities determined by the ASTM D-698 tests. Specimens of the conditioned and compacted PFBC ash blends were prepared and cured. After curing for a specified curing period, test specimens were tested for unconfined compressive strength and linear expansion, according to ASTM C-109 and C157 procedures. A portion of each of the tested specimens from the unconfined compressive strength tests were analyzed for hydration reaction phases in the ashes by $\mathrm{X}$ ray diffraction, thermogravimetric analysis (TGA), and scanning electron microscopy (SEM). The results of this hydration reaction geochemical testing were presented by Bland and Brown (1997a).

\section{General Chemistry of As-Received PFBC Ashes}

The chemical compositions of the Karhula and AEP Tidd ashes are presented in Table 1. The loss on ignition (LOI) is composed of the moisture and the organic carbon. The LOI in the PFBC ashes has been corrected for mineral carbon. Moistures are less than $0.1 \%$ and the organic carbon contents are less than $2 \%$. The free lime $(\mathrm{CaO})$ content of the PFBC ashes was determined by ASTM C-25 to be in the range of 0.5 to $1.0 \%$. The majority of the lime appears to be carbonated in the form of $\mathrm{CaCO}_{3}$. The chemical compositions of the Karhula-low and AEP Tidd ashes have been presented in Bland et al., (1995a). The Karhula ashes are composed principally of anhydrite ( $\left.\mathrm{CaSO}_{4}\right)$, calcite ( $\left.\mathrm{CaCO}_{3}\right)$, coal ash oxides, and dehydroxylated clays. In addition to these phases, the Tidd ashes contain dolomite $\left((\mathrm{Ca}, \mathrm{Mg})_{2} \mathrm{CO}_{3}\right)$ and periclase $(\mathrm{MgO})$, reflecting the use of a dolomite sorbent. It should be noted that the dolomite is principally in the fly ash, while periclase is principally in the bed ash. Dolomite in the fly ash is probably the result of fine dolomite sorbent being blown through the system without the chance to calcine and interact with the gaseous constituents (Bland et al., 1996; Bigham et al., 1993). 
Table 2. Chemical Composition of the PFBC Ashes

\begin{tabular}{||l|cc|cc|cc||}
\hline \hline Chemical & \multicolumn{2}{|c|}{ Karhula-Low (1) } & \multicolumn{2}{c|}{ Karhula-High (2) } & \multicolumn{2}{c||}{ AEP Tidd } \\
Parameter, wt. \% & Fly Ash & Bed Ash & Fly Ash & Bed Ash & Fly Ash & Bed Ash \\
$\mathrm{SiO}_{2}$ & 37.84 & 47.02 & 29.46 & 6.15 & 25.65 & 8.35 \\
$\mathrm{TiO}_{2}$ & 0.87 & 0.40 & 0.43 & 0.12 & 0.49 & 0.13 \\
$\mathrm{Al}_{2} \mathrm{O}_{3}$ & 14.27 & 14.57 & 12.48 & 4.20 & 11.23 & 3.18 \\
$\mathrm{Fe}_{2} \mathrm{O}_{3}$ & 4.95 & 3.80 & 8.69 & 1.33 & 12.51 & 1.58 \\
$\mathrm{CaO}$ & 21.61 & 16.13 & 23.50 & 42.68 & 16.94 & 31.33 \\
$\mathrm{MgO}$ & 3.07 & 2.23 & 0.84 & 0.52 & 9.39 & 18.45 \\
$\mathrm{~K}_{2} \mathrm{O}$ & 0.97 & 2.09 & 1.27 & 0.05 & 1.24 & 0.14 \\
$\mathrm{Na}_{2} \mathrm{O}$ & 1.55 & 2.37 & 1.07 & 0.51 & 0.58 & 0.35 \\
$\mathrm{P}_{2} \mathrm{O}_{5}$ & 0.76 & 0.50 & 0.50 & 0.95 & 0.25 & 0.34 \\
$\mathrm{SO}_{3}$ & 12.17 & 9.39 & 20.83 & 23.56 & 10.55 & 31.31 \\
$\mathrm{CO}_{2}$ & 0.55 & 1.77 & 0.56 & 18.85 & 9.20 & 4.40 \\
$\mathrm{LOI}^{*}$ & 0.26 & 0.31 & 0.26 & 0.98 & 1.88 & 0.36 \\
$\mathrm{Total}$ & 99.37 & 99.76 & 99.89 & 99.70 & 99.91 & 99.92 \\
\hline
\end{tabular}

(1) Karhula-low are ashes from the combustion of low-sulfur subbituminous coal in Karhula facility

(2) Karhula-high are ashes from the combustion of high-sulfur bituminous coal in Karhula facility

* LOI corrected for carbonate losses

The lack of lime $(\mathrm{CaO})$ in the $\mathrm{PFBC}$ ashes is distinctly different from AFBC ashes, which contain large amounts of lime. In PFBC systems, the partial pressure of $\mathrm{CO}_{2}$ favors both calcination and recarbonization. This results in low lime and high carbonates (calcite) in pressurized $\mathrm{FBC}$ ash.

The chemical characteristics of the leachates generated by the Toxicity Characteristics Leaching Procedure (TCLP), were also determined for the bed ash and fly ash from the Karhula-Low and AEP Tidd ash sources. These data are presented in Table 3.

The data substantiate that none of the leachates generated from the PFBC ashes exceed the Resource Conservation and Recovery Act (RCRA) limits. As such, these ashes would NOT be classified as hazardous. Ashes from other coal-fired power systems are already categorized as nonhazardous and have been given an exclusion from these RCRA requirements.

Table 3. Summary of the TCLP Leachate Analysis for PFBC Ashes

\begin{tabular}{||l||c||cc||cc||}
\hline \multicolumn{1}{|c||}{ Chemical Parameter } & \multicolumn{1}{|c||}{ Regulatory Limit, } & \multicolumn{2}{c||}{ Karhula-Low (1) } & \multicolumn{2}{c||}{ AEP Tidd } \\
mg/L & Fly Ash & Bed Ash & Fly Ash & Bed Ash \\
Arsenic (As) & 5.0 & 0.041 & 0.035 & 0.064 & $<0.005$ \\
Barium (Ba) & 100 & 0.395 & 0.241 & 0.091 & 0.136 \\
Cadmium (Cd) & 1.0 & $<0.010$ & $<0.010$ & $<0.010$ & $<0.010$ \\
Chromium (Cr) & 5.0 & 0.014 & $<0.008$ & $<0.008$ & $<0.008$ \\
Lead (Pb) & 5.0 & $<0.100$ & $<0.100$ & $<0.100$ & $<0.100$ \\
Mercury (Hg) & 0.2 & $<0.002$ & $<0.002$ & $<0.002$ & $<0.002$ \\
Selenium (Se) & 1.0 & $<0.200$ & $<0.200$ & $<0.200$ & $<0.200$ \\
Silver (Ag) & 5.0 & $<0.010$ & $<0.010$ & $<0.010$ & $<0.010$ \\
pH & na & 9.2 & 8.0 & 9.1 & 10.5 \\
\hline
\end{tabular}

na - not applicable

(1) Karhula-low are ashes from the combustion of low-sulfur subbituminous coal in Karhula facility 


\section{Physical Properties of PFBC Ashes}

The general physical properties of the ashes were determined, including particle size distribution, specific gravity, and bulk densities. The bulk density and specific gravity of the as-received ashes are presented in Table 4. The bulk densities of the Karhulalow, Karhula-high, and AEP Tidd fly ashes and bed ashes were determined according to ASTM procedures. The minimum or poured densities range from $49.2 \mathrm{pcf}\left(795 \mathrm{~kg} / \mathrm{m}^{3}\right)$ to $59.2 \mathrm{pcf}(948 \mathrm{~kg} / \mathrm{m} 3)$ for the fly ashes and ash range from $80.2 \mathrm{pcf}\left(1285 \mathrm{~kg} / \mathrm{m}^{3}\right)$ to $85.4 \mathrm{pcf}$ $(1368 \mathrm{~kg} / \mathrm{m} 3)$ for the bed ashes. The maximum or packed bulk densities range from $65.6 \mathrm{pcf}\left(1051 \mathrm{~kg} / \mathrm{m}^{3}\right)$ to $74.3 \mathrm{pcf}(1190$ $\mathrm{kg} / \mathrm{m}^{3}$ ) for the fly ashes and from $87.2 \mathrm{pcf}$ $\left(1397 \mathrm{~kg} / \mathrm{m}^{3}\right)$ to $95.4 \mathrm{pcf}\left(1528 \mathrm{~kg} / \mathrm{m}^{3}\right)$ for the bed ashes.

Specific gravities for the PFBC fly ashes range from 2.34 to $2.76 \mathrm{~g} / \mathrm{cc}$ and for the bed ashes range from 2.55 to $2.98 \mathrm{~g} / \mathrm{cc}$.

The size distribution of the bed ash and fly ash is similar to that of other PFBC ashes reported in the literature (Bigham, et al., 1993).

\section{PFBC Ash Use Testing}

Laboratory and pilot-scale tests were conducted to address the use of Karhula and Tidd PFBC ash in a number of constructionrelated applications, including (1) cement replacement and cement manufacturing, (2) fills and embankment construction, (3) soil stabilization applications, (4) synthetic aggregate production, and (5) soil and mine spoil amendments.

Concrete and Cement Production PFBC ash may be used in concrete and in cement production (1) as a replacement of cement in portland cement concrete; (2) as a pozzolanic material in the production of pozzolanic cements (e.g., Type IP); and (3) as a set retardant interground with cement as a replacement for gypsum.

Cement Replacement. The use of PFBC ash as a pozzolan for replacement of portland cement in concrete products is dependent on the results of the ASTM C-311 testing and the specifications of ASTM C-618. The fly ashes from Karhula and AEP Tidd were tested according to ASTM 311. The results are presented in Table 5 .

Table 4. Summary of the Bulk Densities and Specific Gravities of the PFBC Ashes

\begin{tabular}{|c|c|c|c|}
\hline $\begin{array}{l}\text { Physical } \\
\text { Properties }\end{array}$ & $\begin{array}{c}\text { Poured Minimum Bulk } \\
\text { Density, kg/m3 (pcf) }\end{array}$ & $\begin{array}{c}\text { Packed Maximum Bulk } \\
\text { Density, kg/m3 (pcf) }\end{array}$ & $\begin{array}{c}\text { Specific Gravity } \\
\text { g/cc }\end{array}$ \\
\hline \multicolumn{4}{|c|}{ Karhula-Low (1) } \\
\hline Fly Ash & $948(59.2)$ & $1162(72.5)$ & 2.34 \\
\hline Bed Ash & 1368 (85.4) & $1528(95.4)$ & 2.55 \\
\hline \multicolumn{4}{|c|}{ Karhula-High (2) } \\
\hline Fly Ash & 795 (49.6) & 1051 (65.6) & 2.73 \\
\hline Bed Ash & 1289 (80.5) & 1397 (87.2) & 2.81 \\
\hline \multicolumn{4}{|l|}{ AEP Tidd } \\
\hline Fly Ash & 854 (53.3) & $1190(74.3)$ & 2.76 \\
\hline Bed Ash & $1285(80.2)$ & $1443(90.1)$ & 2.98 \\
\hline
\end{tabular}

(1) Karhula-low are ashes from the combustion of low-sulfur subbituminous coal in Karhula facility

(2) Karhula-high are ashes from the combustion of high-sulfur bituminous coal in Karhula facility 
Table 5. ASTM C-311 Test Results for PFBC Fly Ashes

\begin{tabular}{|c|c|c|c|c|c|}
\hline & \multirow{2}{*}{$\begin{array}{l}\text { Karhula } \\
\text { Low (1) } \\
\text { Fly Ash }\end{array}$} & \multirow{2}{*}{$\begin{array}{l}\text { Karhula } \\
\text { High (2) } \\
\text { Fly Ash } \\
\end{array}$} & \multirow{2}{*}{$\begin{array}{c}\text { AEP } \\
\text { Tidd } \\
\text { Fly Ash } \\
\end{array}$} & \multicolumn{2}{|c|}{$\begin{array}{l}\text { ASTM C-618 } \\
\text { Specifications }\end{array}$} \\
\hline & & & & Class F & Class $\mathbf{C}$ \\
\hline Chemical Properties & & & & & \\
\hline$\overline{\mathrm{SiO}_{2}+\mathrm{Al}_{2} \mathrm{O}_{3}+\mathrm{Fe}_{2} \mathrm{O}_{3}}$, wt. $\%$ & 57.57 & 50.63 & 49.39 & $70 \mathrm{~min}$ & $50 \mathrm{~min}$ \\
\hline Sulfur Trioxide, wt.\% & 12.17 & 20.83 & 10.55 & $5 \max$ & $5 \max$ \\
\hline Moisture Content, wt. \% & 0.09 & 0.15 & 0.11 & $3 \max$ & $3 \max$ \\
\hline Loss on Ignition, wt. $\%$ & 0.81 & 0.82 & 11.08 & $6 \max$ & $6 \max$ \\
\hline Available Alkalis, wt.\% & 0.70 & 1.16 & 0.68 & $1.5 \max$ & $1.5 \max$ \\
\hline Physical Properties & & & & & \\
\hline $\begin{array}{l}\text { Fineness, \% retained } 325 \text { mesh } \\
\text { Pozzolanic Activity Index }\end{array}$ & 25.58 & 37.83 & 21.97 & $34 \max$ & $34 \max$ \\
\hline With PC*, \% of control @ 28 days & 83.4 & 59.4 & 89.8 & $75 \mathrm{~min}$ & $75 \mathrm{~min}$ \\
\hline Water Requirement, $\%$ of control & 97.7 & 102.5 & 98.3 & $105 \max$ & $105 \max$ \\
\hline Soundness - Autoclave Expansion, \% & -0.040 & -0.059 & 0.000 & $0.8 \max$ & $0.8 \max$ \\
\hline Drying Shrinkage Increase @ 28 days, \% & 0.016 & 0.027 & 0.011 & $0.03 \max$ & 0.03 max \\
\hline
\end{tabular}

*PC - portland cement

(1) Karhula-low are ashes from the combustion of low-sulfur subbituminous coal in Karhula facility

(2) Karhula-high are ashes from the combustion of hightlfur bituminous coal in Karhula facility

The data indicate that the ashes do not qualify as pozzolans according to ASTM C-311 because the sulfate levels exceed the ASTM C-618 specification of 5\% maximum $\mathrm{SO}_{3}$ content. This will restrict the use of certain PFBC ashes as pozzolans for portland cement applications.

Portland Cement Production PFBC ash can be incorporated into the cement manufacturing process as an ingredient in the clinker production and secondly as an interground material in the production of
Type IP pozzolanic cements. The characteristics of the ash for these applications are defined under ASTM C-595 and C-593. The use of ash as a pozzolan in blended cement according to ASTM C-595 does not rely on the chemical properties of the pozzolan and instead is based on performance specifications for the resultant blended cement. Calculations related to the potential use of the PFBC ashes in the manufacturing of blended Type IP cement are presented in Table 6.

Table 6. Summary of Chemical Specifications for PFBC Ash Use in Type IP Cement

\begin{tabular}{|l|c|c|c|c|}
\hline $\begin{array}{l}\text { Chemical } \\
\text { Requirements }\end{array}$ & $\begin{array}{c}\text { Karhula -Low } \\
\text { Fly Ash (1) }\end{array}$ & $\begin{array}{c}\text { Karhula-High } \\
\text { Fly Ash (2)a }\end{array}$ & $\begin{array}{c}\text { AEP Tidd } \\
\text { Fly Ashb }\end{array}$ & $\begin{array}{c}\text { ASTM C-595 } \\
\text { Specifications }\end{array}$ \\
\hline MgO, \% & 2.9 & 2.5 & 4.0 & 5.0 Max. \\
SO3, \% & 2.9 & 2.9 & 2.9 & 4.0 Max. \\
LOI, \% & 1.0 & 1.0 & 1.8 & 5.0 Max. \\
Fly Ash Addition, \% & 23.8 & 13.9 & 18.0 & - \\
Gypsum Required, \% & - & - & 2.15 & - \\
\hline
\end{tabular}

a. Calculations are based on fly ash interground with Type I portland cement to achieve (1) equivalent of $5 \%$ gypsum addition or (2) a maximum of $4 \% \mathrm{MgO}$ content in cement.

(1) Karhula-low - ashes from the combustion of low-sulfur subbituminous coal in Karhula facility

(2) Karhula-high - ashes from the combustion of high-sulfur bituminous coal in Karhula facility 
It is clear that PFBC ash could be used in substantial amounts in Type IP portland cement.

Structural Fills and Embankments The application of PFBC residue as an engineered material for structural fills and embankments represents a large-scale use option. Structural fills and embankments are numerous in the road construction, mining, and industrial construction industries.

In addition to these compacted fill applications, there is potential use of PFBC ash in controlled density low-strength flowable fill (CDLSFF) applications. This material is not really concrete and is highly flowable (slump 9-10 inches). CDLSFF is usually mixed in a ready-mix concrete truck, with mixing continuing during transport to prevent segregation. The CDLSFF is discharged and placed using chutes or can be pumped using standard concrete or grout equipment. A number of applications have been documented for CDLSFF, including excavatable backfills and trench/pipe bedding, structural fills, road bases, caisson and pile fills, and mine void filling. PFBC ash is expected to be marketable in both compacted fill and flowable fill applications.

Geotechnical tests were conducted to determine the possible use of these ashes as compacted structural fill or embankment material, as well as flowable fill material for excavatable trench grade and structural fill applications. A description of the results of testing for each of these engineered fill materials is provided below.

Compacted Fills and Embankments The geotechnical tests related to compacted structural fills and embankments focused on the moisture-density relationship (Proctors), unconfined compressive strength, expansion and swell, and permeability.

Moisture-density relationships were determined using ASTM D-698 and ASTM D-1557 compactive efforts. The compactive effort employed in the ASTM D-1557 tests is higher than that for ASTM D-698. The compactive efforts represented by these methods typically cover the range of compaction achievable with standard construction equipment.

The results are presented in Table 7. The lower optimum moisture and higher maximum dry density observed for the bed ash is consistent with the larger particle size and specific gravity of the bed ash relative to the fly ash. The ASTM D-698 and D-1557 data are consistent with the expected behavior of different compactive efforts (i.e., lower optimum moisture and higher maximum dry density for increased compactive effort).

Testing addressed the strength development of the two Karhula and the AEP Tidd ash blends as related to their use in compacted structural fills and embankments. The ash blends are a composite of the fly ash and the bed ash in approximate proportions to those produced in the combustor. Specimens prepared at ASTM D-698 and D-1557 moistures and densities were cured under sealed conditions at $23^{\circ} \mathrm{C}$.

Strength development for the Karhula and AEP Tidd ash blends under sealed conditions for different compactive efforts is presented in Figure 1. The strength development of the Karhula PFBC ash is a factor of 4 to 10 times higher than that for other soils and fill materials, while the strength of the AEP Tidd ash was even higher. 
Table 7. Summary of the Moisture-Density Relationships for the PFBC Ashes.

\begin{tabular}{|c|c|c|c|c|}
\hline & \multicolumn{2}{|c|}{ ASTM D-698 } & \multicolumn{2}{|c|}{ "ASTM D-1557 } \\
\hline & $\begin{array}{c}\text { Optimum } \\
\text { Moisture, } \\
\text { wt. \% }\end{array}$ & $\begin{array}{l}\text { Maximum } \\
\text { Dry Density, } \\
\text { kg/m } / \mathbf{m}^{3} \text { (pcf) }\end{array}$ & $\begin{array}{c}\text { Optimum } \\
\text { Moisture, } \\
\text { wt. \% }\end{array}$ & $\begin{array}{c}\text { Maximum } \\
\text { Dry Density, } \\
\text { kg/m } \mathbf{m}^{3} \text { (pcf) }\end{array}$ \\
\hline \multicolumn{5}{|l|}{ Karhula-Low (1) } \\
\hline Fly Ash & 28.98 & 1397 (87.2) & 26.59 & 1488 (92.9) \\
\hline Ash Blend & 24.83 & $1505(94.0)$ & 21.24 & $1594(99.5)$ \\
\hline \multicolumn{5}{|l|}{ Karhula-High (2) } \\
\hline Fly Ash & 40.21 & $1125(70.2)$ & 31.92 & $1263(78.8)$ \\
\hline Ash Blend & 24.6 & $1413(88.2)$ & 24.83 & $1505(94.0)$ \\
\hline \multicolumn{5}{|l|}{ AEP Tidd } \\
\hline Fly Ash & 24.32 & $1636(102.1)$ & 22.33 & $1656(103.3)$ \\
\hline Ash Blend & 20.08 & $1760(109.9)$ & 17.70 & $1819(113.6)$ \\
\hline
\end{tabular}

(1) Karhula-low - ashes from the combustion of low-sulfur subbituminous coal in Karhula facility

(2) Karhula-high - ashes from the combustion of high-sulfur bituminous coal in Karhula facility

The differences in strength between the Karhula and AEP Tidd ashes are related to differences in the hydration reaction chemistry of the two ashes (Bland, 1995a). The ASTM D-1557 compacted specimens were stronger than the ASTM D-698 compacted specimens.

The expansion properties of the conditioned and compacted Karhula and AEP Tidd ashes were determined according to modified

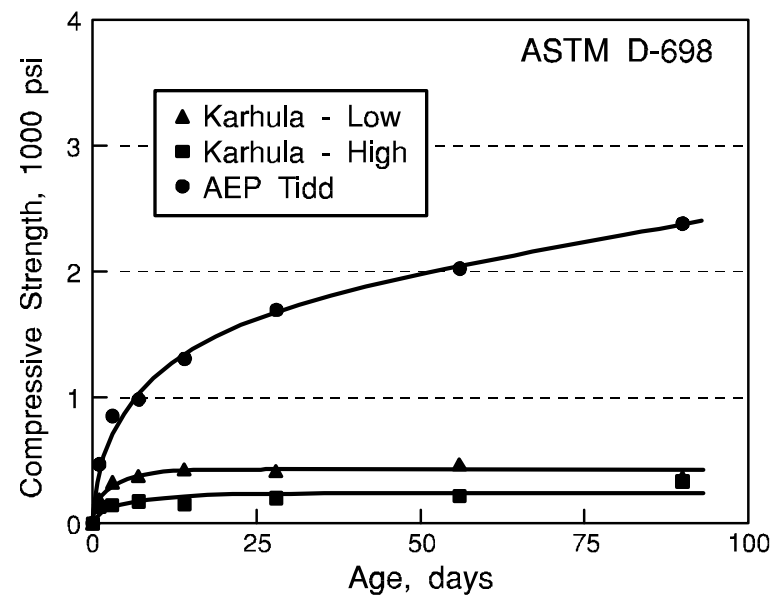

ASTM C-157 procedures in which the expansion is essentially unrestricted.

The results for the Karhula and AEP Tidd ash blends for ASTM D-698 and D-1557 compactive efforts are essentially identical, with expansion of near zero percent. In addition, the ASTM D-698 and D-1557 compacted ash blend specimens cured under both sealed and saturated conditions showed essentially no expansion.

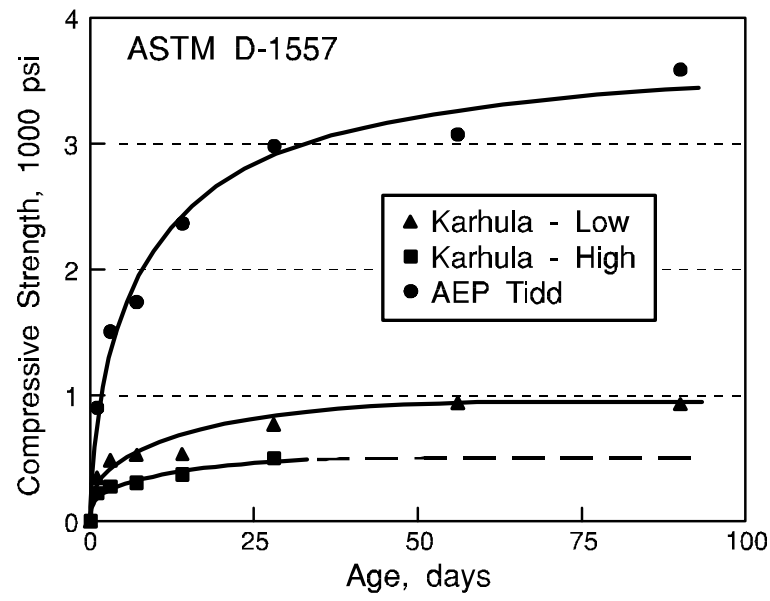

Figure 1. Strength Development of PFBC Ash Blends, Sealed Cured at $23^{\circ} \mathrm{C}$ 
Table 8. Hydraulic Conductivity of ASTM D-698 and D-1557 Compacted PFBC Ash

\begin{tabular}{||l|c|c||}
\hline \multirow{2}{*}{\begin{tabular}{l|c||} 
Karhula-Low Ash Blend (1) \\
Initial
\end{tabular}} & $\begin{array}{c}\text { ASTM D-698 } \\
\mathbf{k , ~ c m} / \mathbf{s e c}\end{array}$ & $\begin{array}{c}\text { ASTM D-1557 } \\
\mathbf{k , ~ c m} / \mathbf{s e c}\end{array}$ \\
\cline { 2 - 3 } 28 day & & \\
Karhula-High Ash Blend (2) & $9.1 \mathrm{E}-6$ & $2.6 \mathrm{E}-6$ \\
Initial & $6.2 \mathrm{E}-6$ & $1.4 \mathrm{E}-6$ \\
28 day & & \\
AEP Tidd Ash Blend & $1.1 \mathrm{E}-5$ & $6.0 \mathrm{E}-6$ \\
$\quad$ Initial & $6.0 \mathrm{E}-6$ & $3.9 \mathrm{E}-6$ \\
28 day & & $2.3 \mathrm{E}-8$ \\
\hline \hline
\end{tabular}

(1) Karhula-low - ashes from the combustion of low-sulfur subbituminous coal in Karhula facility

(2) Karhula-high - ashes from the combustion of high-sulfur bituminous coal in Karhula facility

The permeabilities or hydraulic conductivities (k) of the PFBC ash blends were determined according to ASTM procedures. The ashes were compacted at ASTM D-698 and D-1557 optimum moisture and density. The results are presented in Table 8 .

As expected, the permeability of the PFBC ash blends continued to decrease with curing. Hydraulic conductivities in the range of $10^{-5}$ to $10^{-7} \mathrm{~cm} / \mathrm{sec}$ were determined at early ages for the ASTM D-698 compacted ash blends and continued to decrease with time to $10^{-6}$ to $10^{-8} \mathrm{~cm} / \mathrm{sec}$ at 28 days. These values are typical of those reported for CFBC ashes (Georgiou, et al., 1993).

The ASTM D-1557 compacted ash blends were less permeable than the D-698 compacted ash blends. Typically, the ASTM D-1557 specimens were half to an order of magnitude less permeable than the ASTM D698.

Controlled Density Low-Strength Flowable Fills. The second fill application involves controlled density low-strength flowable fill material, which has been used in construction applications for a number of years. Controlled density low-strength flowable fill material is a mixture of cement, fly ash, sand, and water that has a specific strength dependent upon the end use. CDLSFF offers favorable economics compared to other fill materials because it requires less excavation and compaction during construction.

The results of tests using Karhula and AEP Tidd PFBC ashes in CDLSFF are represented in Table 9. Structural fill grade CDLSFF, requiring in excess of $6.89 \mathrm{MPa}(1000 \mathrm{psi})$ strength, and excavatable trench fill grade, requiring strengths in the range of 700 to $1400 \mathrm{kPa}$ (100 to $200 \mathrm{psi}$ ), were tested. The data clearly show that both the Karhula and the AEP Tidd fly ashes can be used as CDLSFF.

Soil Stabilization Agents The use of PFBC ash and other FBC residues for stabilization of soils is a potentially large ash use market. This ash use application is similar to the cement stabilization of soils commonly applied in the construction industry.

Soil stabilization is based on the treatment of clay soils with a material to provide strength and stability. Cement-fly ash and lime-fly ash mixtures are commonly employed at levels of 10 to $20 \%$ of the soil. FBC ashes exhibit selfcementing characteristics and, as such, have been proposed as a viable stabilizing agent. 
Table 9. Summary of Properties of Flowable Fill Materials Made with PFBC Ash

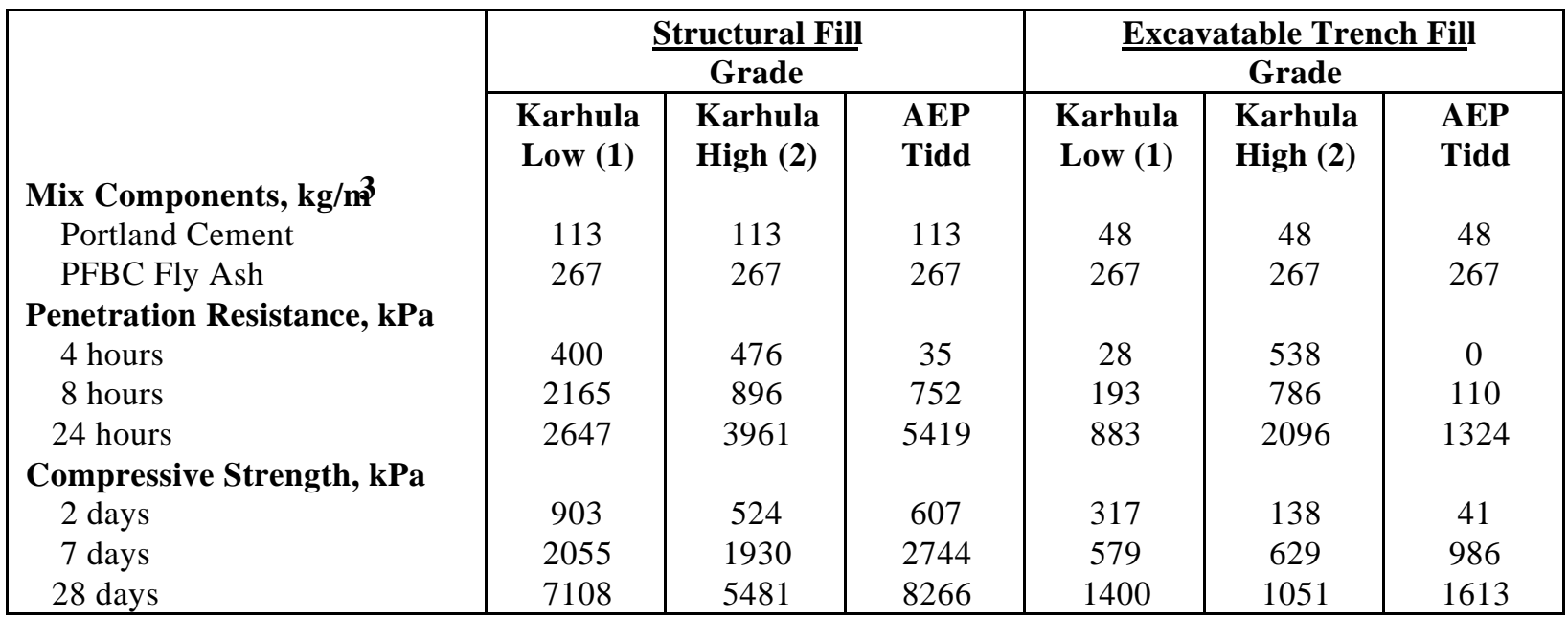

na-not available

(1) Karhula-low are ashes from the combustion of low-sulfur subbituminous coal in Karhula facility

(2) Karhula-high are ashesfrom the combustion of high-sulfur bituminous coal in Karhula facility

For a material to be considered as a cementing agent for soil stabilization applications, the material must show strength development, freeze/thaw durability, and wet/dry durability in compliance with ASTM D-1632, D-560, and D-559, respectively. A viable cementing material needs to exhibit strength in the range of $4000 \mathrm{psi}$ and durability of 12 cycles of freeze/thaw and wet/dry for the cementing material only. These requirements result from stabilized soil specifications of $2.76 \mathrm{MPa}(400 \mathrm{psi})$ and durability to 12 cycles of wet/dry and

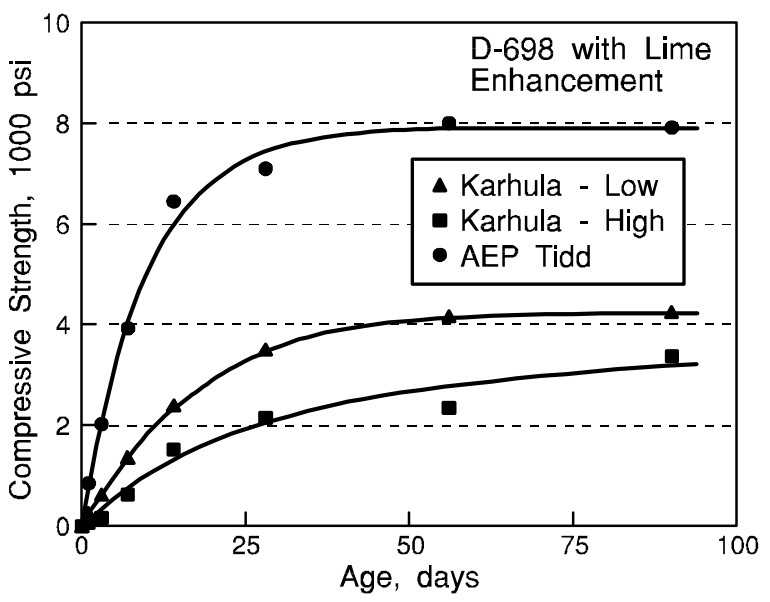

freeze/thaw when soils are treated at 10 to $20 \%$ cementing levels.

Unconfined Compressive Strength Relationship Testing was conducted using the Karhula and AEP Tidd ash blends with and without hydrated lime addition, in order to determine their potential as a cementing agent for soil stabilization applications. The test specimens were cured under sealed conditions $\left(23^{\circ} \mathrm{C}\right)$. Typical results of the testing are displayed in Figure 2.

Figure 2. Strength Development of PFBC Ash Blends With Lime Enhancement

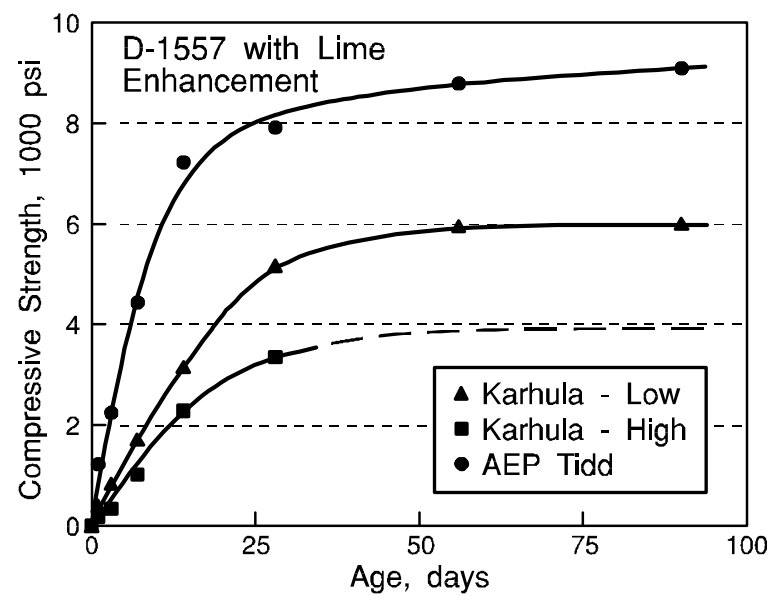


The results showed that the addition of 5\% hydrated lime increased the strength development dramatically (over $41.4 \mathrm{MPa}$ (6,000 psi) at 90 days for Karhula ash and over $62 \mathrm{MPa}(9,000 \mathrm{psi})$ at 90 days for AEP Tidd ash). The ash blend without hydrated lime enhancement showed strengths of less than 6.9 MPa (1000 psi) for the Karhula ash and less than $24.1 \mathrm{MPa}(3,500 \mathrm{psi})$ for the AEP Tidd ash.

As mentioned earlier, these differences in strength are due to differences in the hydration chemistry of the two ashes (Bland, 1995a, 1997). The low strengths of the ash blends without lime are sufficient for many applications, such as fills and embankments. However, for other applications, such as soil stabilization, lime enhancement will be required at some level (e.g., 5\% or less).

Expansion Properties The expansion properties of the conditioned and compacted Karhula and AEP Tidd ashes with and without hydrated lime addition were tested for soil stabilization applications, according to a modified ASTM C-157 procedure. Tests were conducted on ASTM D-698 and D1557 compacted ash bars. The results for the ASTM D-698 compacted PFBC ashes with and without lime and cured under sealed and saturated conditions are shown in Table 10.

The lime-enhanced Karhula ash blend showed expansion of approximately $1.5 \%$, while the ash blend without lime enhancement showed essentially no expansion. The expansion noted for the lime-enhanced ash appears to occur early, within the first 20 to 30 days. Although the expansion is significant, it appears controllable and manageable, and it should be possible to balance the strength and swelling properties in certain applications. For example, in certain grouting applications, such as subsidence control in underground construction operations, controlled expansion of the magnitude reported is desirable.

Table 10. Expansion Results for PFBC Ashes With and Without Lime Enhancement

\begin{tabular}{||l|cc|cc|cc||}
\hline \multirow{2}{*}{ Linear Expansion, \% } & \multicolumn{2}{|c|}{ Karhula-Low (1) } & \multicolumn{2}{c|}{ Karhula-High (2) } & \multicolumn{2}{c||}{ AEP Tidd } \\
& $\begin{array}{c}\text { Sealed } \\
\text { Curing }\end{array}$ & $\begin{array}{c}\text { Saturated } \\
\text { Curing (3) }\end{array}$ & $\begin{array}{c}\text { Sealed } \\
\text { Curing }\end{array}$ & $\begin{array}{c}\text { Saturated } \\
\text { Curing (3) }\end{array}$ & Sealed & Saturated \\
Curing & Curing (3) \\
7 days & & & & & & \\
90 days & -0.007 & $(3)$ & 0.000 & $(3)$ & 0.003 & $(3)$ \\
180 days & 0.000 & 0.044 & 0.000 & 0.036 & -0.022 & 0.062 \\
365 days & 0.004 & 0.071 & 0.000 & 0.071 & 0.000 & 0.058 \\
2 years & 0.013 & 0.062 & na & na & 0.022 & 0.111 \\
Lime Enhancement & 0.022 & 0.178 & na & na & 0.089 & 0.151 \\
7 days & & & & & & \\
90 days & 0.928 & $(3)$ & 0.000 & $(3)$ & 0.047 & $(3)$ \\
180 days & 1.494 & 1.534 & 0.111 & 0.218 & 0.018 & 0.093 \\
365 days & 1.440 & 1.556 & 0.116 & 0.244 & 0.031 & 0.093 \\
2 years & 1.422 & 1.548 & na & na & 0.102 & 0.173 \\
\hline
\end{tabular}

na-not available

(1) Karhula-low are ashes from the combustion of low-sulfur subbituminous coal in Karhula facility

(2) Karhula-high are ashes from the combustion of high-sulfur bituminous coal in Karhula facility

(3) Specimens submerged in ash/water slurry after 14 days sealed curing. 
Freeze/Thaw and Wet/Dry Cycle Durability Conditioned and compacted Karhula and AEP Tidd ash blend specimens were subjected to 12 cycles of freeze/thaw (ASTM D-560) and wet/dry (ASTM D-559) conditions. The results indicated that all of the PFBC ashes with $5 \%$ hydrated lime enhancement survived the entire 12 cycles with losses less than the $15 \%$ maximum limit. Typical losses of less than $5 \%$ were determined.

\section{Synthetic Aggregate Production The} aggregate market encompasses conventional aggregate products, such as masonry units and ready-mix concrete. Also, with crushing, aggregates can be produced for use in asphalt paving, road base construction, and roller compacted concrete. Lightweight aggregate can also be used in many structural building products.

Synthetic aggregate has been manufactured from power plant ash that can meet the requirements for conventional aggregate products, such as masonry units and readymix concrete. With crushing, synthetic aggregate can be produced for use in asphalt paving, road base construction and rollercompacted concrete.

Pelletizing Trials Pelletizing trials were conducted simulating the AET process for the pelletization of FBC ashes, as described in the literature (Bland et al., 1992, 1993a).

Pelletizing trials were conducted at the WRI Waste Management Laboratory, employing a high-speed pin mixer for conditioning of the ash and a 3-foot diameter pelletizing pan for the agglomeration of the conditioned ash into a pelletized form. Pelletizing trials were conducted employing Karhula and AEP Tidd ash blends with and without lime enhancement. The pelletizing addressed the water requirements and other processing parameters pertinent to defining the technical feasibility and relative economics of aggregate production from PFBC ashes.

Pelletized Ash Properties The pelletized aggregate produced from Karhula and AEP Tidd PFBC ashes was tested according to ASTM procedures as they relate to its use in various construction applications. Pelletized ash from each of the pelletizing trials was tested for crush strength, Los Angeles abrasion resistance (ASTM C-131) and soundness (ASTM C-88). The results of testing are presented in Table 11.

The results indicate that without hydrated lime addition, the pelletized PFBC ash does not meet the ASTM or AASHTO construction aggregate requirements of a maximum of $40 \%$ weight loss. However, the addition of $5 \%$ hydrated lime results in compliance with these requirements for construction aggregate. In addition, the soundness of the aggregate using magnesium sulfate solutions was well below the AASHTO specifications of less than $18 \%$ loss after five cycles. In fact, the Karhula aggregate actually gained weight as a result of continued hydration during the five cycles.

\begin{tabular}{lll} 
Soil/Mine & Spoil & Amendment \\
\hline Applications & PFBC & ash
\end{tabular} amendment for agricultural and reclamation activities represents a potentially large market. A number of benefits can result from the application of PFBC residue to agricultural soils or mine spoils, including the modification of soil $\mathrm{pH}$, supply of essential plant micro-nutrients for crop production, increasing water infiltration, and modification of soil structure, promoting root growth. 
Table 11. Summary of the Properties of PFBC Ash-Based Synthetic Aggregate

\begin{tabular}{|l|ccc|ccc|}
\hline $\begin{array}{l}\text { Aggregate } \\
\text { Properties* }\end{array}$ & \multicolumn{3}{|c|}{ No Lime Enhancement } & \multicolumn{3}{c|}{ Lime Enhancement } \\
& $\begin{array}{c}\text { Karhula } \\
\text { Ash (1) }\end{array}$ & $\begin{array}{c}\text { Karhula } \\
\text { Ash (2) }\end{array}$ & $\begin{array}{c}\text { AEP } \\
\text { Tidd Ash }\end{array}$ & $\begin{array}{c}\text { Karhula } \\
\text { Ash (1) }\end{array}$ & $\begin{array}{c}\text { Karhula } \\
\text { Ash (2) }\end{array}$ & $\begin{array}{c}\text { AEP } \\
\text { Tidd Ash }\end{array}$ \\
\hline Crush Strength, kg & & & & & & \\
24 hours & 10.4 & 12.3 & 34.0 & 146.6 & 54.9 & 108.9 \\
48 hours & 10.9 & 23.6 & 36.8 & 138.8 & 92.1 & 102.5 \\
$\quad 7$ days & 14.1 & 27.7 & 47.2 & 154.3 & 93.5 & 125.2 \\
28 days & 23.6 & 16.3 & 74.4 & 131.1 & 85.3 & 127.9 \\
LA Abrasion Resistance & & & & & & \\
Grade & $\mathrm{B}$ & $\mathrm{B}$ & $\mathrm{C}$ & $\mathrm{B}$ & $\mathrm{B}$ & $\mathrm{C}$ \\
$\quad$ Loss @ 28 days, \% & 75.29 & 89.14 & 42.1 & 26.07 & $38.9(3)$ & 11.1 \\
Soundness** & & & & & & \\
Loss after 5 cycles, \% & 27.97 & na & 15.08 & -4.23 & na & 2.35 \\
\hline
\end{tabular}

* Curing conditions $-82 \mathrm{C}\left(180^{\circ} \mathrm{F}\right)$ sealed for 24 hours.

** Magnesium sulfate solution.

na-not available

(1) Karhula-low are ashes from the combustion of low-sulfur subbituminous coal in Karhula facility

(2) Karhula-high are ashes from the combustion of high-sulfur bituminous coal in Karhula facility

(3) Results from the $23{ }^{\circ} \mathrm{C}$ curing of the pelletized ash yield $19.22 \%$. Excess moisture loss during curing at $82{ }^{\circ} \mathrm{C}$ is suspected.

The availability of nutrients, such as sulfur, potassium, and phosphorous, along with micronutrients is expected to benefit plant growth. In addition, the neutralization potential of the ash materials can alleviate acid conditions found in many soils. Also, PFBC ash contains anhydrite or gypsum, often used to reclaim sodic materials (i.e., materials influenced by high levels of sodium).

PFBC ashes generated at the Karhula and AEP Tidd plants were evaluated as soil amendments to ameliorate acid and sodic conditions on problem soils. As mentioned earlier, this material was thought to be useful because of its high neutralization potential, high $\mathrm{CaSO}_{4}$ content, and nutritional potential. A very important consideration for the use of this material for ameliorating problem soils was the potential for negative impact of other constituents on the environment. Saturated paste extracts have shown that the ash materials do not contain any elements at concentrations deemed harmful to the environment.

Laboratory Equilibration Study Laboratory equilibration studies were conducted to address the use of PFBC ashes as amendments to ameliorate acidic spoil and soil conditions. The laboratory equilibration study was designed to determine the potential of the ash materials to neutralize the available acid and the potential acidity associated with oxidation of reduced materials present in the spoil. An acid spoil material from Texas was used for the study. Humidity cells were used to simulate the oxidation of acid-forming soils under amended and non-treated conditions. Ag-lime $\left(\mathrm{CaCO}_{3}\right)$ and Karhula fly ash were used as the soil neutralization amendment materials in the equilibrium humidity cell studies. The acid spoil material was treated with three levels of ag-lime and three levels of Karhula fly ash: 
- Level $1=30.4 \mathrm{~g}$ ag-lime or $89.1 \mathrm{~g}$ Karhula fly ash $/ 1000 \mathrm{~g}$ of spoil

- Level $2=26.2 \mathrm{~g}$ ag-lime or $77.4 \mathrm{~g}$ Karhula fly ash/1000 g of spoil

- Level $3=17.6 \mathrm{~g}$ ag-limeor $51.6 \mathrm{~g}$ Karhula fly ash/1000 g of spoil

The amount of ag-lime used was based on the calcium carbonate equivalent (CCE) of the material and the acid/base accounting values of the acid spoil. The PFBC fly ash application rates were equivalent to the acid neutralization potential used for the ag-lime tests. Treatment of acid soils usually employs an application rate of 1.2 times that calculated from the neutralization potential.

The humidity cell equilibration study showed the Karhula fly ash to be an effective acid neutralization amendment (Figure 3). The acid present in the treated materials was neutralized and the formation of acid from acid-forming minerals present in the spoil material was significantly reduced due to treatment with PFBC ashes.

These results compared well with data collected for the ag-lime treatments. It is apparent that the neutralization reaction rate of the Karhula fly ash in raising $\mathrm{pH}$ of the acid spoil is slower than that of the ag-lime. While the Karhula fly ash shows a delayed response, the ag-lime reacted immediately with the spoil material, increasing the $\mathrm{pH}$ and maintaining it with time. Although the Karhula fly ash is an effective long-term amendment for acid soils and spoils, the lower early $\mathrm{pH}$ levels of approximately 4 for the Karhula fly ashtreated spoils may cause some problems with germination and early plant growth with sensitive plant species.

Greenhouse Productivity Study A greenhouse study was conducted to show the influence of PFBC ashes on the productivity of acidic mine spoil containing very high potential acidity.

The greenhouse study compared the production of Garrison Meadow foxtail grass (Alopecuras protensis cult. Garrison) on acid spoil materials amended with ash from the Karhula and AEP Tidd operations and with ag-lime $(\mathrm{CaCO})$.
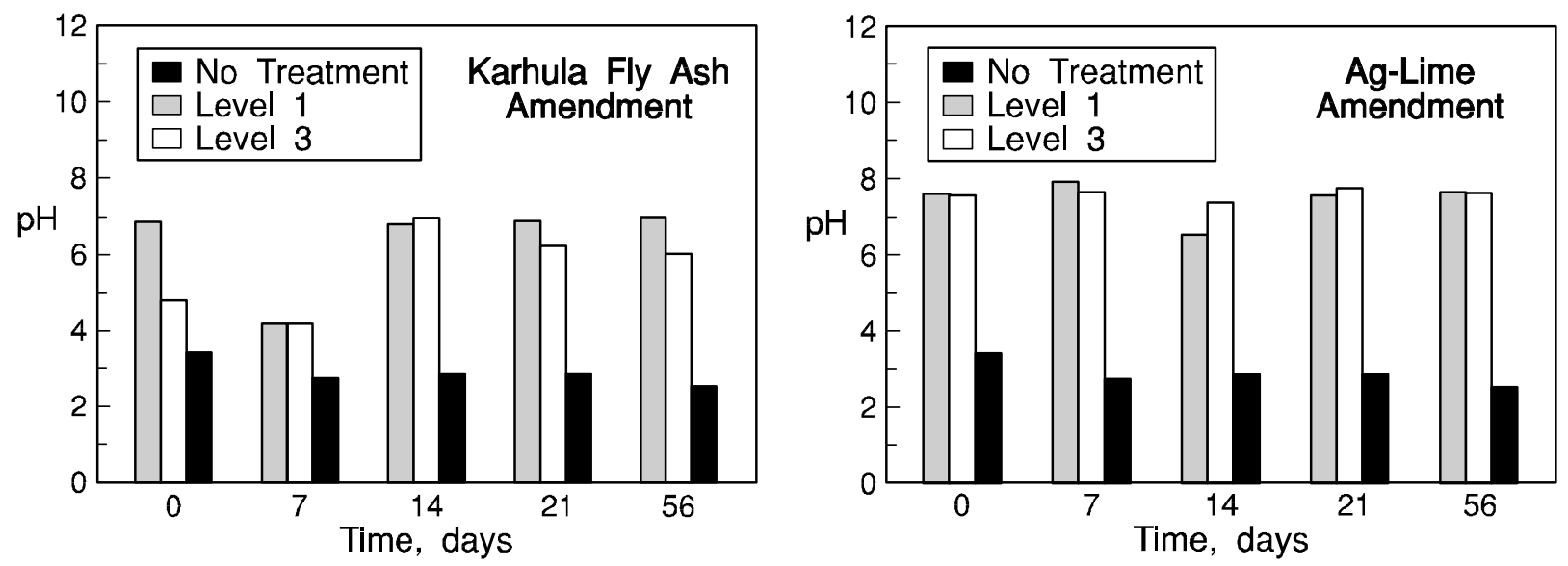

Figure 3. Influence of Ag-Lime and Karhula Fly Ash on Acidic Mine Spoil pH 


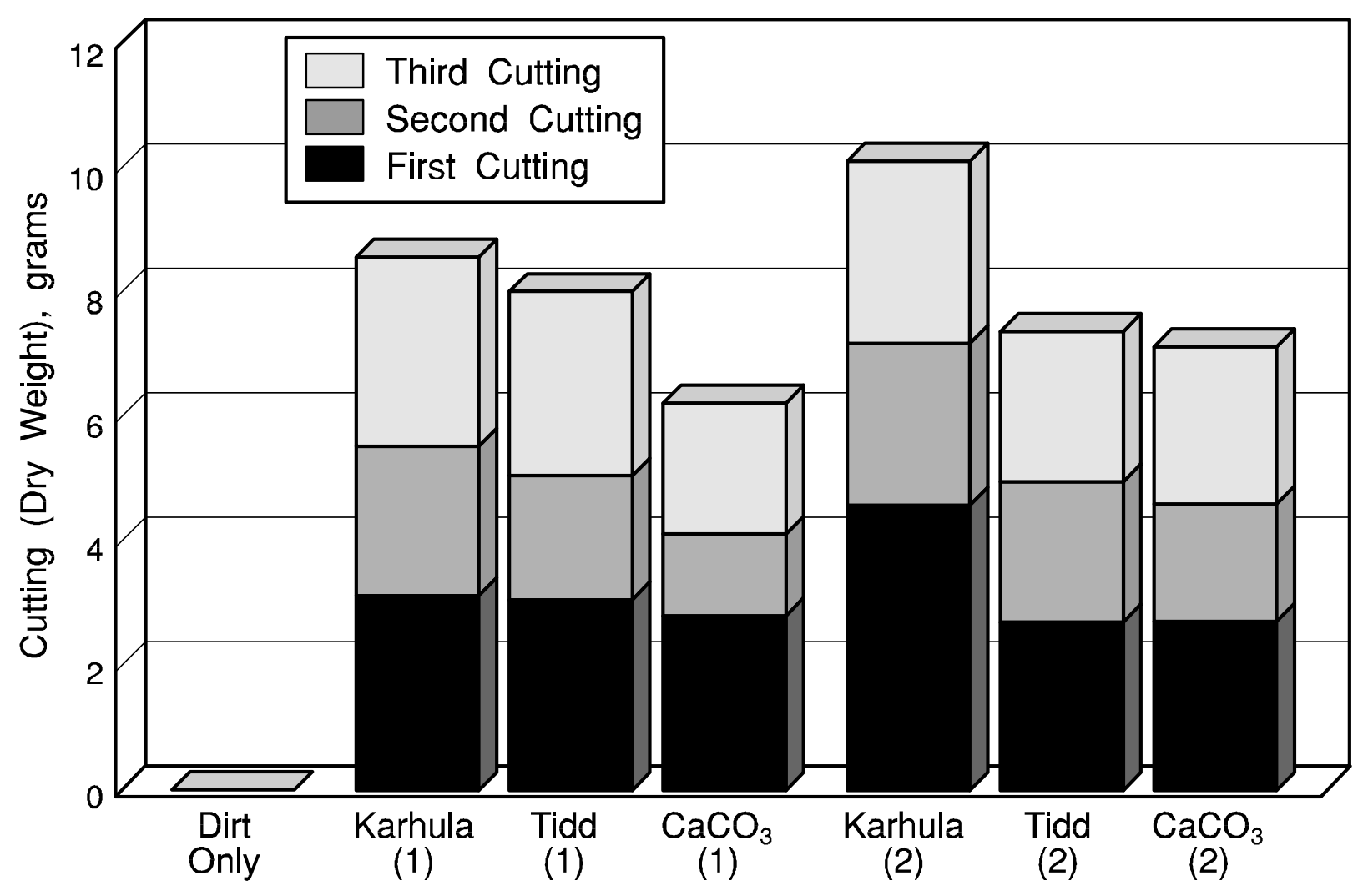

Figure 4. Dry Weight Production of Garrison Meadow Foxtail Grass Grown on Karhula-Low Fly Ash, AEP Tidd Fly Ash, and Ag-Lime Amended Acidic Mine Spoil

Three levels of amendments were applied to the acid soils: (1) no application; (2) level 1 based on acid-base potential using the total sulfur level: $30.4 \mathrm{~g} / \mathrm{kg}$ ag-lime $\left(\mathrm{CaCO}_{3}\right)$, $89.1 \mathrm{~g} / \mathrm{kg}$ Karhula fly ash, and $55.8 \mathrm{~g} / \mathrm{kg}$ Tidd fly ash; and (3) level 2 based on acidbase potential using pyritic sulfur level multiplied by a mixing factor of $2: 26.4 \mathrm{~g} / \mathrm{kg}$ ag-lime (CaCO3), $77.4 \mathrm{~g} / \mathrm{kg}$ Karhula fly ash, and $48.5 \mathrm{~g} / \mathrm{kg}$ Tidd fly ash. The plant productivity data were evaluated statistically using SAS.

The greenhouse study was conducted under controlled conditions of light, temperature, fertilizer levels, and soil moisture requirements to maximize plant growth conditions. Fertilizer additions were based on nitrogen, phosphorous, and potassium levels and did not include concerns for nutrient ratios and micronutrient deficiencies.

The results of the greenhouse study are presented in Figure 4. The results clearly indicate that extremely poor quality soils can be successfully treated with PFBC ashes, resulting in good plant productivity. Total plant production was about $25 \%$ higher for the Tidd and Karhula ash treatments compared to the ag-lime treatment at the high level (Level 1) of application (Figure 4). At the low amendment application rate, the Karhula treatment resulted in plant production about 30\% higher compared to the Tidd and ag-lime treatments, which were comparable. The results show PFBC ashes to be as effective as ag-lime in promoting seed germination and more effective than ag-lime 
in promoting plant production and root penetration.

A potential factor responsible for the differences in the plant production between the PFBC ash-amended spoils and the ag-lime amended spoil was the root penetration. The PFBC ash treated soils contained root matter throughout the potted soil, while much of the root mass in the ag-lime treated soil was associated with the sides of the pots. No problems with the early low $\mathrm{pH}$ were found.

A second greenhouse study is in progress. This greenhouse study is examining all three of the PFBC fly ashes, in addition to the aglime control. Garrison Meadow Foxtail Grass and Common Bermuda Grass are the production species. The duration of the greenhouse study will be sufficient to allow for three cuttings of the grasses. The results of this testing are not available for this paper.

Sodic Soils Amelioration Study Permeability testing of sodic spoil materials collected from a mine site in North Dakota indicated that PFBC ash was an effective treatment, resulting in the potential for enhanced root penetration and gas and liquid movement within the spoil material. The untreated spoil material allowed no water penetration into the material or movement through the material during the permeability tests. Treated material allowed water penetration and movement through the material at a relatively high rate.

Summary The technical feasibility study examined the use of PFBC ash in construction-related applications, including its use as a cementing material in concrete and use in cement manufacturing, fill and embankment materials, soil stabilization, and synthetic aggregate production. Testing was also conducted to determine the technical feasibility of PFBC ash as a soil amendment for acidic and sodic problem soils and spoils encountered in agricultural and reclamation applications.

The results of the technical feasibility testing indicated that PFBC ash represents a viable material for use in currently established applications for conventional coal combustion ashes.

\section{SUMMARY AND CONCLUSIONS}

Western Research Institute, in conjunction with the Electric Power Research Institute, Foster Wheeler International, Inc. and the U.S. Department of Energy, has undertaken a research and demonstration program designed to examine the market potential and the technical feasibility of ash use options for PFBC ashes. Ashes from the Foster Wheeeler Energia Oy pilot-scale circulating PFBC tests in Karhula, Finland, combusting (1) lowsulfur subbituminous and (2) high-sulfur bituminous coal, and ash from the AEP's high-sulfur bituminous coal-fired bubbling PFBC in Brilliant, Ohio, were evaluated in laboratory and pilot-scale ash use testing at WRI.

\section{Market Assessment}

A general review has been conducted of the potential markets for PFBC ash. This review has indicated that there are a number of markets into which PFBC ash, derived from both high-sulfur and low-sulfur coal-fired units, may be able to penetrate. These potential markets include the following:

- Supplementary cementing materials in concrete and cement production;

- Structural fill and embankment material;

- Soil stabilizing agent;

- Synthetic aggregate production; and

- Soil amendment 
Unfortunately, the value of the market products and the availability of competing materials is restricted by transportation distances. Competing materials already established in these markets have substantial technical performance records.

\section{Technical Feasibility of PFBC Ash Use}

The technical feasibility study examined the use of PFBC ash in construction-related applications, including its use as a cementing material in concrete and use in cement manufacturing, fill and embankment materials, soil stabilization agent, and use in synthetic aggregate production. Testing was also conducted to determine the technical feasibility of PFBC ash as a soil amendment for acidic and sodic problem soils and spoils encountered in agricultural and reclamation applications.

The results of the technical feasibility testing indicated the following:

- PFBC ash does not meet the chemical requirements as a pozzolan for cement replacement. However, it does appear that potential may exist for its use in cement production as a pozzolan and/or as a set retardant.

- $\quad$ PFBC ash shows relatively high strength development, low expansion, and low permeability properties that make its use in fills and embankments promising.

- Testing has also indicated that PFBC ash, when mixed with low amounts of lime, develops high strengths, suitable for soil stabilization applications and synthetic aggregate production. Synthetic aggregate produced from $\mathrm{PFBC}$ ash is capable of meeting ASTM/AASHTO specifications for many construction applications.

- The residual calcium carbonate and calcium sulfate in the PFBC ash has been shown to be of value in making PFBC ash a suitable soil amendment for acidic and sodic problem soils and mine spoils.

PFBC ash represents a viable material, as evidenced by the WRI findings, for use in many of the currently established applications for conventional coal combustion ashes. As such, PFBC ash should be viewed as a valuable resource, and commercial use opportunities for these materials should be explored for planned PFBC installations.

\section{Conclusions}

In conclusion, there is a significant market potential for PFBC ash in the construction and soil amendment industries. PFBC ash should be viewed as a valuable resource, and commercial opportunities for these materials should be explored for future PFBC installations.

\section{ACKNOWLEDGMENTS}

The authors acknowledge the support of the Electric Power Research Institute, Foster Wheeler Energy International, Inc.; and the U. S. Department of Energy (DOE), Federal Energy Technology Center (FETC), under Cooperative Agreement Number DE-FC2193MC30127. However, any opinions, findings, conclusions, or recommendations expressed herein are those of the authors and do not necessarily reflect the views of the DOE.

The authors also wish to acknowledge the contribution of American Electric Power Services for supplying the ashes from AEP 
Tidd, suggestions and assistance of Kumar M. Sellakumar of Foster Wheeler Energy International, Inc., and Kamal Das of U. S. DOE FETC for his project support and assistance.

\section{REFERENCES}

Anthony, E.J., A.P. Iribarne and J.V. Iribarne, 1995, "Study of Hydration During Curing of Residues From Coal Combustion with Limestone Addition." Proceedings, 13th International Conference on Fluidized Bed Combustion, Orlando, FL, p. 11131121.

Baker/TSA, Inc., 1990, "Waste Disposal/Utilization Study." U.S. Department of Energy, Morgantown Energy Technology Center, Morgantown, WV, DOE/MC/25042-2872, 335pp.

Beeghly, J.H., Dick, W.A., and W.E. Wolfe, 1995, "Developing Technologies for High Volume Land Application Uses of pressurized Fluidized-Bed Combustion (PFBC) Ash." Proc., 13th International Conference On Fluidized Bed Combustion, May, 7-10, 1995, Orlando, FL, p.1243-1257.

Bennett, O.L., J.L. Hern, R.L. Reid, H.D. Perry, W.L. Stout, and J.H. Edward, 1985, "Agricultural Uses of Atmospheric Fluidized Bed Combustion Residue (AFBCR)-A Seven Year Study." Unpublished Report, U.S. Department of Agriculture, Appalachian Soil and Water Conservation Research Laboratory, Beckley, WV.

Berry, E.E., R.T. Hemmings and B.J. Cornelius, 1991, "Commercialization Potential of AFBC Concrete: Part 2. Mechanistic Basis for Cementing Action."
Electric Power Research Institute, Palo Alto, CA, EPRI GS-7122, Vol. 2.

Bigham, J., W. Dick, L. Forster, F. Hitzhusen, E. McCoy, R. Stehouwer, S.W. Traina, W. Wolfe, and R. Haefner, 1993, "Land Application Uses for Dry FGD By-Products; Phase I Report." U.S. Department of Energy, Morgantown Energy Technology Center, Morgantown, WV.

Bland, A. E., C. E. Jones, J. G. Rose, and M. N. Jarrett, 1987. "Production of NoCement Concretes Utilizing Fluidized Bed Combustion Waste and Power Plant Flyash." Proc., 9th International Conference on Fluidized Bed Combustion, Boston, May 3-7, 1987 pp 947-953.

Bland, A.E., C.E. Jones, J.G. Rose, and J.L. Harness, 1989a, "Ash Management Options for Bubbling FBC Technologies." Proc., ASME Joint Power Generation Conference, Dallas, Oct. 22-26, FACT Vol. 6, pp 9-19.

Bland, A.E., C.E. Jones, J.G. Rose, and J.L. Harness, 1989b, "Ash Management Options for AFBC." Proc., 10th International Conference on Fluidized Bed Combustion, San Francisco, April 30 May 3, 1989, pp 323-333.

Bland, A.E., S.M. Burwell, and R.K. Kissel, 1991a, "Commercialization Potential of AFBC Concretes: Part 1. Mix Design and Engineering Properties." EPRI Project No. 2708-4, 1991, EPRI Report GS7122.

Bland, A.E., R.K. Kissel, and G.G. Ross, 1991b, "Utilization of CFBC Ashes in Roller Compacted Concrete 
Applications." Proc., 11th International Conference on Fluidized Bed Combustion, Montreal, Canada, April, 1991, pp 857-863.

Bland, A.E., R. Cox, A. Rowen, E.R. Lichty, and R.A. Schumann, 1992, Pelletizing Ash, United States Patent Number 5,137.753, August 11, 1992.

Bland, A.E., R. Cox, A. Rowen, and E.R. Lichty, 1993a, "Pelletization as an Ash Management Option for CFBC Ash Handling and Utilization." Proc., 12th International Conference on Fluidized Bed Combustion, La Jolla, CA, May, 1993, pp 1341-1350.

Bland, A.E, D.N. Georgiou, and E.J. Anthony, 1993b, "Seawater Conditioning of CFBC Ash". Proc., 12th International Conference on Fluidized Bed Combustion, La Jolla, CA, p. 835-846.

Bland, A.E., 1994, "Overview of Management Options for Residues from FBC Technologies." Proc., EPRI 1994 Fluidized Bed Combustion Symposium, Atlanta, May, 1994.

Bland, A.E., 1995a, "Hydration Reaction Chemistry Associated with Management of Pressurized Fluidized Bed Combustion Ash." Proc., 1995 Ash Utilization Symposium, University of Kentucky and ACAA, Lexington, KY.

Bland, A.E., T.H. Brown, D.N. Georgiou, L.J. Young, M.B. Ashbaugh and J.M. Wheeldon, 1995b, "Use Potential of Ash From Circulating Pressurized Fluidized Bed Combustion Using Low-Sulfur Subbituminous Coal." Proc., 13th International Conference on Fluidized Bed
Combustion, ASME, Orlando, FL, pp 1229-1242.

Bland, A. E., T. H. Brown, L.-J. Young and J. Wheeldon, 1995c, "Pressurized Fluidized Bed Combustion Ash Management Options." Proc., Power Gen Americas '95, December, 1995, Anaheim, CA.

Bland, A. E., and T. H. Brown, L.-J. Young, 1996, "Market Assessment and Technical Feasibility Study of Pressurized Fluidized Bed Combustion Ash Use". Proc., Advanced Power Systems '96 Conference, June, 1996, U.S. DOE, Morgantown, WV.

Bland, A. E. and T. H. Brown, 1997a, "Hydration Reaction Chemistry Associated with Management of Pressurized Fluidized Bed Combustion Ash." Proc., 14th International Conference on Fluidized Bed Combustion, Vancouver, BC, May 11-14, 1997, pp 683-692.

Bland, A.E., T.H. Brown, and J.M. Wheeldon, 1997b, "Pressurized Fluidized Bed Combustion-Part I. ConstructionRelated Use Options." FUEL, Vol. 76, p.733-740.

Brown, T.H. and Bland, A.E., 1997c, "Pressurized Fluidized Bed CombustionPart II. Soil and Mine Spoil Amendment Use Options." FUEL, Vol 76, p. 741-748

Burwell, S.M., R.K. Kissel, A.E. Bland, and D.M. Golden, 1993, "Fluidized Bed Combustion Ash Concrete." Proc., 12th International Conference on Fluidized Bed Combustion, La Jolla, CA, May, 1993, pp 847-858. 
Dearborn Chemical Co. Limited, 1991, "Evaluation of Selected Management Options for Circulating Fluidized Bed Combustion Solid Residues." Final Report to Industrial Programs Branch, Environmental Protection Programs Directorate, Environment Canada, DDS File No. KE144-9-6134.

Georgiou, D.N., A.E. Bland, and D. Sundstrom, 1993, "Laboratory Evaluation of a Low Sulfur Coal CFBC Residue as a Structural Fill." Proc., 12th International Conference on Fluidized Bed Combustion, La Jolla, CA, May, 1993, pp 629-639.

Hunsacker, D., G.W. Sharpe, J.G. Rose, and R.C. Deen, 1987, "Road Base Construction Utilizing Coal Waste Materials." Proc., Eighth International Ash Utilization Symposium, Washington, D.C., October, pp 22-1 to 22-15.

Iribarne, A. P., E. J. Anthony, and J. Blondin, 1993, "The Phase Analysis of Coal Combustion Residues." Proc., 12th International Conference on Fluidized Bed Combustion, La Jolla, CA, May 9-13, 1993, pp 641-647.

Korcak, R. F., 1980, "Fluidized Bed Combustion Material as a Lime Substitute and Calcium Source for Apple Seedlings." J. Environmental Quality, Vol. 9, pp. 147-151.

Minnick, L.J., 1982, "Development of Potential Uses for the Residue from Fluidized Bed Combustion Processes." Final Report; Report No. DOE/ET/10415-T6, U.S. Department of Energy.
Pitman, D.W., 1986, "Construction of Roller Compacted Concrete Pavement." Transportation Research Board 1062, Washington, D.C. pp 1-6.

Sidle, R.C., W.L. Stout, J.L. Hern, and O.L. Bennett, 1978, "Leaching Experiments on Soil and Mine Spoil Treated with Fluidized Bed Combustion Waste." Proc., 5th International Conference on Fluidized Bed Combustion, 1978, pp 821-831.

Stout, W. L., H. A. Menser, O. L. Bennett, and W. M. Winant, 1982, "Cover Establishment on an Acid Mine Spoil Using Composted Garbage Mulch and Fluidized Bed Combustion Residue." Reclamation and Revegetation Research, Vol. 1, pp 203-211.

Stout, W.L., J.L. Hern, R.F. Korcak, and C.W. Carlson, 1988, "Manual for Applying Fluidized Bed Combustion Residue to Agricultural Lands." U.S. Department of Agriculture, Agr. Res. Ser., ARS-74.

Stehouwer, R., and P. Sutton, 1992, "Treatment of Acid Mine Spoil with Dry FGD By-Products: Leachate Quality and Plant Growth." Proc., Abandoned Mine Lands Conference, Aug. 23-26, 1992, Chicago, IL. 